\title{
Role Schools In The Implementation Of Extracurricular Drumband In Mi Muhammadiyah
}

\author{
${ }^{1 s t}$ Pratik Hari Yuwono \\ Universitas Muhammadiyah \\ Purwokerto \\ Indonesia \\ pratikyuwono@gmail.com
}

\author{
${ }^{2 n d}$ Yudha Febrianta \\ Universitas Muhammadiyah \\ Purwokerto \\ Indonesia \\ yudhafebrianta@ump.ac.id
}

\author{
${ }^{3 r d}$ Tri Yuliansyah Bintaro \\ Universitas Muhammadiyah \\ Purwokerto \\ Indonesia \\ triyuliansyahbintaro@ump.ac.id
}

\begin{abstract}
This study was conducted to determine the role of the principal, the coach of the marching band and the school committee in the marching band at MI Muhammadiyah learning Ajibarang Kulon. This study is a qualitative research method that use descriptive qualitative. The experiment was conducted in MI Muhammadiyah Ajibarang Kulon, District Ajibarang, Banyumas. Data collection techniques used using interview techniques, observation and documents. Technique authenticity of data using triangulation data. The results of this study are principals in extracurricular activities at MI Muhammadiyah Ajibarang drumband Kulon in charge and controlling role drumband extracurricular activities, coach drumband acted as arranger who arranged the songs and became manager in managing the marching band at MI Muhammadiyah Ajibarang Kulon, students perperan as a player running extracurricular activities marching band, school committees play a supportive school programs in developing extracurricular activities drumband, parents role to support and motivate children to provide moral support and material, as well as using methods suzuki talent coach education. Based on the results of this study concluded that the implementation of extracurricular drumband in MI Muhammadiyah Ajibarang Kulon can run well and be able to perform for each role can be run well, but there are still shortcomings in terms of the marching band instruments that are currently available. perperan students as a player running extracurricular activities drumband, school committees play a supportive school programs in developing drumband extracurricular activities, parents role to support and motivate children to provide moral support and material, as well as using methods suzuki talent coach education. Based on the results of this study concluded that the implementation of extracurricular drumband in MI Muhammadiyah Ajibarang Kulon can run well and be able to perform for each role can be run well, but there are still shortcomings in terms of the marching band instruments that are currently available.
\end{abstract}

Keywords: The role of school, extracurricular Drumband Execution Methodlearning Drumband

\section{INTRODUCTION}

Schools are institutions of formal education which aims to shape the behavior and skills of students in the field of intellectual and skill. Act of the National Education System No. 2 of article 9 paragraph 2 of 1989 states that the school is part of a tiered and continuous educationwhich has formal responsibility, scientific, and functional.Schools have an important role in developing students' abilities better cognitive abilities, affective, and psychomotor.

Schools as formal educational institutions not only play a role in the development of intra-curricular activities, but also extracurricular activities should receive special attention to hone and develop the student's ability. It thus also conducted in MI Muhammadiyah Ajibarang Kulon, District Ajibarang, Banyumas. MI Muhammadiyah Ajibarang Kulon is one of the favorite schools prioritized by local communities for school activities both intra and extra running balanced, evidenced by the achievement diarih by students. There are some extracurricular activities that can be followed by students MI Muhammadiyah Ajibarang Kulon among which Hizbul Wathan, hadroh, marching band, painting, and dance. Extracurricular marching band is the most preferred by students, it is no wonder if this extracurricular also receive special attention from the school. One extracurricular to train students in establishing cooperation and student practice concentration is drumband.

States that the marching band is a band consisting of drums as the core, and the music field consisting of many instruments[1]. Drumband extracurricular activities at MI Muhammadiyah Ajibarang Kulon trained by the school teachers who do have knowledge and experience in the marching band. Drumband good game resulting from the process of serious and sustained exercise. The role of the coach is very reliable in selecting teaching methods and strategies in the marching band. Coaches have a role in organizing, training, and provide isntruksi against drumband extracurricular participants. In addition to coaches, principals also instrumental in supporting the advancement of the marching band, control and supervise the activities of the marching band, as well as being a pioneer spirit in meajukan marching band at school. Selection of appropriate methods and strategies will be easier for students to receive disampaiakan material so as to produce a good game of the marching band. Through the right method will excite and interest the students in the exercise thus indirectly the student will be disciplined in the marching band practice.

Based on the above research will explore more deeply related to the role of schools and methods used in the implementation of the marching band at MI Muhammadiyah 
extracurricular Ajibarang Kulon. Extracurricular certainly will not be able to run properly if the school does not contribute massively to develop such activities. The use of appropriate methods will also affect the success in the implementation of extracurricular drumband. The method is often used in teaching the art of marching band music including Carl Off method, the method codaly, Dal Croze, suzuki talent and education.

\section{THEORETICAL BASIS}

\section{1. understanding Roles}

States that "the role (role) is a dynamic aspect of the position (status)"[2]. If someone fulfilling their obligations and rights under the kedudukanya he perform the role. The role has three important meaning that it includes norms, social status, and the role of the individual.Led to that role covers three areas:

a. The role includes norms associated with the position or one's place in society. The role in this sense is a series of rules that guide a person in public life.

b. The role is a concept of what can be done by individuals in the community as an organization.

c. The role can also be regarded as individual behavior that are important to the social structure of society. [2].

2. Method of Playing Music

The method is a way that teachers use to achieve the learning objectives. "music is a way of teaching methods adopted to achieve the objective of a music teaching in stages according to the level of a logical sequence"[3]. The sequence of music learning activities shall follow the stages of the requisite degree of sequence of musical ability and level of the material order of music teaching logical.

Music training methods are often used in the world of music, including:

a. Kodaly method

Based on national journals,entitled Method Development Kodaly in the introduction of notes on Early Childhood explains that the model Zoltan Kodaly (read: Koh-DAI), a composer and collector of folk music of Hungarian origin, develop curriculum-based songs and movement for child. Kodaly method of music education approach is based on the philosophy of Zoltan Kodaly. Zoltan Kodaly was a Hungarian composer, author, educator and expert in Hungarian folk songs. Music learning method using Kodaly approach can support the development of children, namely:

1) "Literacy" music can help children in the process of reading, writing and thinking musically rights and can be done every human being,

2) Learning music must start from the sound itself,

3) Listening to music should be started as early as possible to support the child's development in the future.
Musical ability and musical concepts should be taught through folk songs as a folk song is a song that no doubt contributed to the world of education. [4]

\section{b. Method Carl Off}

Carl Orff method of music education that puts rhythmic blows in ansamble groups and prepare the melody in diantonicscale percussion instruments[1]. Based on these opinions can be concluded in the methods developed by Carl Orff is elaborated innovative approach to music education in children. Music elemental and combines movement, singing, playing and improvising. It is intended that your child can easily catch a given musical material. Playing and singing will create a fun atmosphere for students who are not directly the students are learning about music.

c. Suzuki Talent Education method

In the journal entitled Standardization of Results LearnMusic Arts in Elementary and Secondary Education, argued that Suzuki learning method is now used almost all over the world compete with Carl Orff method, Zoltan Khodally and Dal Croze [5]. Also in the national journal Martopo Day (2005), titled Music as Important Factors in Application of Quantum Learning methods explained in Japan after World War II, Method Suzuki (Suzuki Violin Method) creation Shinichi Suzuki was born also to meet the challenges of vocational education and taste. Suzuki method is basically attempting to teach simple music that young children of pre-school age have been able to start to learn music without going through an aptitude test first. The nature of the Suzuki Method for adopting technique learn their mother tongue (Mother-Tongue), which emphasizes the aspect imitate (imitation),

\section{Extracurricular}

Based on Minister of National Education Republic of Indonesia Number 39 of 2008 on the Development of Students [7] extracurricular activities is one of the lines of student coaching. Extracurricular activities are followed and implemented by the students both at school and outside of school, aims to enable students to enrich and extend themselves. "Extracurricular activities created method of play (game) both play a serious, proposial (group) eg scouting and playing alone" [8]. The definition above can be concluded that the extracurricular activities aimed at developing an interest talent students with methods of playing (games) are proportional.

4. music Drumband

"The marching band is a band consisting of drums as the core, and the music field consisting of many instruments" [1]. Drumband also guided by a leader called a majorette. Linggono (2008: 277-391) describes the instruments used in marching band is as follows:
a. Glockenspiel
b. Snare drum
c. cymbals 

d. Tom-tom
e. bass drum
f. Stick drumband

\section{METHODS}

This study used a qualitative approach with descriptive methods. Qualitative research is research that aims to understand the phenomenon of what is experienced by the subject of the study such as behavior, perception, motivation, action, and others, in a holistic manner, and by way of description in the form of words and language, in a specific context natural and by using various natural methods. The research was conducted in MI Muhammadiyah Ajibarang Kulon.

Researchers identify the role of schools and methods used in extracurricular the implementation of the drumband in MI Muhammadiyah Ajibarang Kulon. Researchers use a variety of resources to collect data to support research. Leverage data using several techniques, namely, observation (observation), in-depth interviews, and documentation.

\section{RESULTS AND DISCUSSION}

Results of researchthat have been carried out by researchers about the role of schools and methods used in the marching band at MI the implementation of the extracurricularMuhammaddiyah Ajibarang Kulon. Based on data analysis conducted by researchers both data interviews, observation and documentation of the obtained results of further research that researchers will present data based on the following research theory study:

\section{1. role of Schools}

a. Role of the Principal

The principal role, a role that is very much to be done includes the principal, responsible as a leader, Manager, innovator, motivator, controlling and supervisior. On the implementation of extracurricular drumband in MI Muhammadiyah Ajibarang Kulon menjalanakan role as a school principal in charge of extracurricular activities drumband and as extracurricular activities drumband controller. The school principal MI Muhammadiyah Ajibarang Kulon make drumband into extracurricular programs as well as a compulsory school for grades 3, 4, and 5 . drumband extracurricular activities can make students become more creative, active, and training cooperation among individual students. In addition to the role that has been described above is done principals collaboration with other educational elements also greatly help the progress of the marching band at MI Muhammadiyah Ajibarang Kulon. Collaboration is done for example, is trying to bring a coach drumband collected in PDBI to exchange knowledge and experience with the coach drumband in MI Muhammadiyah Ajibarang Kulon so the marching band at MI Muhammadiyah Ajibarang Kulon always featuring new innovations in the marching band played music.
As has been stated by Soekanto that role (role) is a dynamic aspect of the position (status), if the person carrying out the rights and obligations in accordance with the position he perform the role. So is conducted by the principal MI Muhammadiyah Ajibarang Kulon has the highest position at the same time responsible for all activity conducted including extracurricular school marching band. So we can conclude that the theory presented by Soekanto it has in common the results that the principal has a position and implement its obligations then perform the role of the school principal in charge and as controlling drumband extracurricular activities at MI Muhammadiyah Ajibarang Kulon.

b. Coach role Drumband

Coach drumband MI Muhammadiyah Ajibarang Kulon role as manager and arranger of songs. Songs that are taught include religious songs, children's songs, national songs, to songs dangdut when children ask for the song. The model used in the game marching band Ajibarang MI Muhammadiyah boys Kulon model.

In addition to the role played by the coach over, coach drumband MI Muhammadiyah Ajibarang Kulon also always give motivation to their students both in practice and in the following race. Motivation is necessary to establish confidence for students.

Role theory put forward the role is a concept of what can be done by individuals in the community as an organization [2]. This shows behavior patterns made by Coach drumband MI Muhammadiyah Ajibarang Kulon have reciprocity with other social actors, namely against the team drumband MI Muhammadiyah Ajibarang Kulon. The theory put forward by Soekanto have an equation with penenlitian result, the similarity is that the coach behaviors do have reciprocal of the school where the coach plays a role in learning drumband. Coach is one factor supporting the passage of the marching band at MI Muhammadiyah extracurricular Ajibarang Kulon.

c. The role of the School Committee

The school Committee is very supportive of the programs that has been defined as any school extracurricular programs drumband. Drumband activities in Muhammadiyah MI Ajibarang Kulon got special attention from the school Committee, moral or material support continue to be provided by the school Committee against the drumband on MI Muhammadiyah Ajibarang Kulon. The support provided since the school drumband became one of pride for the community and Ajibarang in general school community in General from the successful achievements earned. The role (role) is a dynamic aspect of the position (status) [2]. The theory described by Soekanto in accordance with the findings that the school committee in carrying out its role is able to deliver the marching band at MI Muhammadiyah Ajibarang Kulon won a wide range of achievements. Thus the role of the school 
committee also strongly supports the success of Muhammadiyah Ajibarang Kulon drumband MI in achievement.

d. Learning Method Drumband

Learning the marching band at MI Muhammadiyah Ajinarang Kulon begins by playing a melody that is by playing a musical instrument belera and pianika to her students understand the play. The next stage is to practice techniques accompaniment. Musical instruments used include snare, drum, bass drum, triotom, and cymbals. Coach teaches accompaniment techniques ranging from the very simple pattern samapai into intricate patterns. Menyesuaiakan accompaniment to the songs sung while the punches were used that hit single, double, and triple.

Coach or teacher in delivering material to its students through several stages. In teaching the material requires some method such as the method of lecture, discussion, demonstration, drill or exercise, and the method of administration tasks [6]. Coach drumband MI Muhammadiyah Ajibarang Kulon in teaching marching band using the methods of teaching using the Suzuki Talent Education, this method is adopting the technique of learning the mother tongue is to emphasize the aspect imitate (imitation), repeating (repettion), and memorize or recall (memory) in its application approach emphasizes love.

\section{CONCLUSION}

Based on the discussion of research has been done then obtained some results that can be inferred, among others:

1. The role of the school is a collaboration undertaken by the school community includes principals, teachers or coaches, students, school committees and parents. On the implementation of the marching band at MI Muhammadiyah extracurricular Ajibarang Kulon run each role. The school principal plays a role as responsible and controlling the implementation of extracurricular drumband. The coach acts as manager and arranger in the marching band playing musical instruments. Students act as well as the factors supporting the marching band player extracurricular drumband implementation. Committees play a supportive school marching band extracurricular activities, and parents play a supportive and motivation to their children so active in extracurricular activities drumband.

2. The method used in teaching drumband coach in MI Muhammadiyah Ajibarang Kulon is Suzuki Talen Education. Through this method the students becomes easier to accept the material presented trainer so as to display a good marching band and of course the requirements for achievement.
[1] Banoe, P. (2003). Kamus Musik. Yogyakarta: Kanisius.

[2] Soekanto, S. (2001). Sosiologi Sebagai Pengantar. Jakarta: Rajawali Press

[3] Safrina, R. (2002). Pendidikan Seni Musik. Bandung: CV Maulana

[4] Wulandari, R (2013). "Pengembangan Metode Kodaly Dalam Pengenalan Nada Pada Anak Usia Dini. Jurnal Penelitian Ilmu Pendidikan. 6, (2). (53-55)

[5] Astuti, Kun S. (2004). "Standarisasi Evaluasi Belajar Seni Musik Pada Pendidikan Dasar Dan Menengah". Jurnal Nasional. 2, (2), 199-204

[6] Linggono, Budi I. (2008). Seni Musik Nonklasik Jilid 3. Jakarta: Direktorat Pembinaan Sekolah Menengah

[7] Peraturan Menteri Pendidikan Nasional Republik Indonesia. (2008).

[8] Kinardi. (2011). Dunia Marching Band. Jakarta: Eksatama

Permendiknas RI Nomor 39 Tahun 2008 tentang Pembinaan Kesiswaan. Jakarta: Permendiknas

\section{REFERENCES}

